\title{
SANKSI PIDANA PLAGIARISME DALAM HUKUM POSITIF DI INDONESIA
}

\author{
Oleh Hulman Panjaitan ${ }^{1}$ \\ Email: hulmanpanjaitan@uki.ac.id \\ Universitas Kristen Indonesia
}

\begin{abstract}
One of the norms that must be obeyed by everyone when writing a scientific literature is to mention the source of citation and other people's opinion, this has been acknowledged among academics especially in universities, the most fundamental fact is, many writers do not pay attention to this matter or they do it intentionally, if this matter is done, then this action is called plagiarism and the person who performs the action is called a plagiarist, in regard to this matter, the law regulates the matter by imposing a criminalthreat.
\end{abstract}

Keyword: Sanksi Pidana Plagiarisme

\section{Pendahuluan}

Bagian dari proses pembelajaran dan tidak jarang merupakan komponen penilaian untuk kelulusan suatu mata kuliah, setiap dosen akan memberikan penugasan kepada mahasiswanya untuk menghasilkan suatu karya ilmiah ${ }^{2}$ dalam bentuk paper atau makalah. Kenyataan dalam praktik, sebagai akibat kemajuan teknologi, tidak jarang para mahasiswa mengambil jalan pintas yang cepat dengan mengunduh dan/atau mengambil pendapat atau ide atau karya ilmiah orang lain dari google atau internet dengan cara copy paste tanpa menyebutkan sumbernya. Tidak saja dalam bentuk makalah tetapi bahkan dalam bentuk skripsi di tataran mahasiswa S-1 maupun thesis dan disertasi di tataran mahasiswa S-2 dan S-3.

Tidak disadari bahwa apa yang dilakukannya adalah pelanggaran hukum yang mengakibatkan kerugian bagi orang lain. Tindakan atau perbuatan seperti ini lebih dikenal dengan plagiarisme, yang secara sederhana dapat diartikan sebagai tindakan mengambil karya/ide atau pendapat orang lain seolah-olah menjadi karya/ide atau pendapat sendiri tanpa menyebutkan sumbernya. Berbagai berita di media cetak dan elektronik terkait plagiarism dan

\footnotetext{
${ }^{1}$ Penulis adalah Dekan pada Fakultas Hukum Universitas Kristen Indonesia, Jakarta.

2 Menurut Peraturan Menteri Pendidikan Nasional Republik Indonesia No. 17 Tahun 2010 tentang Pencegahan dan Penanggulangan Plagiat di Perguruan Tinggi, yang dimaksud dengan karya ilmiah adalah hasil karya akademik mahasiswa/ dosen/peneliti/tenaga kependidikan di lingkungan perguruan tinggi yang dibuat dalam bentuk tertulis baik cetak maupun elekronik yang diterbitkan dan/atau dipresentasekan.
}

bahkan ada yang dikenakan sanksi administratif berupa penurunan pangkat atau pencopotan seseorang dari jabatannya hingga pembatalan gelar akademik atau Guru Besar yang telah diberikan. Namun jarang diketahui adanya sanksi pidanabagi seorang plagiator. Plagiarisme sudah merupakan kejahatan intelektual.

Banyak orang beranggapan sudah merupakan budaya masyarakatdi Indonesiakurangmemberikan penghargaan dan penghormatan terhadap karya cipta orang lain sebagai bagian dari hak kekayaan intelektual seseorang. Akibatnya Indonesia pernah dikecam sebagai salah satu negara pelanggar hak kekayaan intelektual yang tinggi di dunia. Tahun 2010 berdasarkan survey yang dilakukan oleh Political and Economic Risk Consultancy(PERC), Indonesia adalah pelanggar hak atas kekayaan intelektual terburuk di Asia dengan menempatkan Indonesia pada angka 8,5 dari angka maksimum 10 yang berarti menduduki posisi teratas diantara 1 negara lain dikawasan Asia. Dibawah Indonesia ada Vietnam $(8,4)$, China (7,9), Filipina $(6,8)$, India $(6,5)$, Thailand $(6,1)$ dan Malasya $(5,8) .^{3}$

Marak dan larisnya $\mathrm{CD} / \mathrm{VCD}$ bajakan di pasaran, cukup membuktikan hipotesa di atas. Di bidang karya ilmiah, hal semacam ini dikenal dengan plagiarism. Adanya plagiarism adalah lebih disebabkan kurangnya penghormatan dan penghargaan atas karya, ide atau pendapat orang

\footnotetext{
3 Hulman Panjaitan dan Wetmen Sinaga, Performing Right Hak Cipta atas Karya Cipta Musik dan Lagu, Indo Hill Co, Jakarta, 2010, halaman 8.
} 
lain. Selain itu, faktor malas dan tidak jujur juga sangat mempengaruhi.Sekalipun harus diakui bahwa pengembangan ilmu pengetahuan bukanlah berdiri sendiri dan terlepas dari pengembangan dan kemajuan ilmu pengetahuan pada masa sebelumnya, maka tidak pula harus ragu dan malu untuk secara jujur mengakui dan mencantumkan sumbernya atau rujukannya. Karena hal seperti itu merupakan sikap jujur dan integritas sebagai ciri seorang ilmuwan atau akademik.

Dilatarbelakangi maraknya tindakan dan perbuatan plagiarisme di lingkungan perguruan tinggi sekaligus menunjukkan political will dari pemerintah terhadap tindakan plagiarisme di Indonesia, maka permasalahan tentang plagiarisme diatur dan mendapat tempat dalam UU No. 20 Tahun 2003 tentang Sistem Pendidikan Nasional yang kemudian secara organik ditindak lanjuti melalui Peraturan Menteri Pendidikan Nasional Republik Indonesia No. 17 Tahun 2010 tentang Pencegahan dan Penanggulangan Plagiat di Perguruan Tinggi, sekalipun sebelumnya telah diatur dalam Kitab Undang Undang Hukum Pidana dan peraturan perundang-undangan hak cipta lainnya yang pernah berlaku di Indonesia. ${ }^{4}$

\section{Permasalahan}

Bagaimana bentuk sanksi pidana plagiarisme dalam hukum positif?

\section{Tujuan Penelitian}

Untuk mengetahui bentuk sanksi pidana plagiarisme dalam hukum positif

\section{Pengertian Plagiarisme dan Ruang Lingkupnya}

Secara etimologi, plagiarisme yang dalam bentuk kata kerja adalah "to plagiarize" secara harfiah adalah berarti menjiplak atau menyontek. Echols dan Shadily menterjemahkan plagiarisme sebagai penjiplakan, plagiat. Pelakunya disebut plagiator (plagiatorist). ${ }^{5}$ Dalam bukunya "Penulisan Karangan Ilmiah", Brotowidjojo mengemukakan bahwa plagi-arisme adalah hasil pembajakan atau penculikan berupa penggunaan fakta, penjelasan, ungkapan dan kalimat orang lain secara tidak sah. Hasil pembajakan, penculikan dan penggunaan

\footnotetext{
${ }^{4}$ Terdapat sejumlah peraturan perundang-undangan hak cipta yang pernah berlaku di Indonesia, mulai dari Auteurswet (stb No. 600 tahun 1912), UU No. 6 Tahun 1982, UU No. 7 Tahun 1987, UU 12 tahun Tahun 1997, UU No. 19 Tahun 2002 dan terakhir dengan UU No. 28 Tahun 2014 tentang Hak Cipta.

5 Echols dan Shadiliy, Kamus Inggris-Indonesia, Gramedia, Jakarta, 1983, halaman 132.

${ }^{6}$ Brotowidjojo, M.D, Penulisan Karangan Ilmiah, Edisi Kedua, Akademika Pressiondo, Jakarta, 1993, halaman 86.
}

fakta, ungkapan dan sebagainya yang tidak sah tersebut disebut plagiat. $^{6}$ Hasil dari plagiarisme adalah plagiat dan pelakunya disebut plagiator.

Lebih lanjut ia menulis: “... sama halnya seperti barang tidak bergerak milik perorangan, maka ide atau fakta baru yang ditemukan atau dikumpulkan, penjelasan, ungkapan, kata-kata adalah milik perorangan yang diakui dan dilindungi oleh undangundang. Karena itu, bila anda menggunakannya dalam tulisan anda, maka anda berkewajiban untuk mengakui bahwa anda meminjam dari orang lain. Bila anda tidak mengatakannya atau pura-pura tidak mengetahui hal itu, maka perbuatan anda termasuk kategori plagiarisme dan pelanggaran undangundang". ${ }^{7}$

Menurut Kamus Besar Bahasa Indonesia, plagiarisme sebagai kata benda adalah penjiplakan yang melanggar hak cipta. Adapun plagiat adalah pengambilan karangan (pendapat, dan sebagainya) orang lain dan menjadikannya seolah-olah karangan (pendapat, dan sebagainya) sendiri, misalnya menerbitkan karya tulis orang lain atas nama dirinya sendiri; jiplakan. Dan plagiator adalah orang yang mengambil karangan (pendapat, dan sebagainya) orang lain dan disiarkan sebagai karangan (pendapat, dan sebagainya) sendiri; penjiplak. ${ }^{8}$

Secara otentik melalui Peraturan Menteri Pendidikan Nasional Republik Indonesia No. 17 Tahun 2010 tentang Pencegahan dan Penanggulangan Plagiat di Perguruan Tinggi, plagiat adalah perbuatan secara sengaja atau tidak sengaja dalam memperoleh atau mencoba memperoleh kredit atau nilai untuk suatu karya ilmiah, dengan mengutip sebagian atau seluruh karya dan/atau karya ilmiah pihak lain yang diakui sebagai karya ilmiahnya tanpa menyatakan sumber secara tepat dan memadai. Sedangkan plagiator adalah orang perseorangan atau kelompok orang pelaku plagiat, masing-masing bertindak untuk diri sendiri, untuk kelompok atau untuk dan atas nama suatu badan.

Dalam praktiknya, dikenal bentuk atau yang termasuk ruang lingkup dari plagiarisme, yaitu:

1. Mengutip kata-kata atau kalimat orang lain tanpa menyebutkan sumbernya atau asalnya.

2. Menggunakan gagasan, pandangan atau pendapat orang lain tanpa menyebutkan sumbernya atau asalnya.

3. Menggunakan data atau informasi milik orang

\footnotetext{
${ }^{7}$ Ibid, halaman 86-87.

${ }^{8}$ Departemen Pendidikan Nasional, Kamus Besar Bahasa Indonesia, Edisi Ketiga, Balai Pustaka, Jakarta, 2005, halaman 879.
} 
lain tanpa menyebutkan sumbernya atau asalnya.

4. Mengakui karya atau tulisan atau pendapat orang lain sebagai tulisan sendiri.

5. Melakukan parafrase ${ }^{9}$ tanpa menyebutkan sumbernya atau asalnya.

6. Menyerahkan suatu karya ilmiah yang dihasilkan dan/atau diumumkan oleh pihak lain seolah-olah sebagai karyanya sendiri.

Dalam kaitannya dengan bentuk plagiarisme, Soelistyo mengemukakan ada beberapa tipe dari plagiarisme, ${ }^{10}$ yaitu:

1. Plagiarisme kata demi kata (word for word plagiarism).

Penulis menggunakan kata-kata penulis lain (pércis) tanpa menyebutkan sumbernya.

2. Plagiarisme atas sumber (plagiarism of source).

Penulis menggunakan gagasan orang lain tanpa memberikan pengakuan yang cukup tanpa menyebutkan sumbernya secara jelas.

3. Plagiarisme kepengarangan (plagiarism of authorship).

Penulis mengakui sebagai pengarang karya tulis karya orang lain.

4. Self Plagiarism

Termasuk dalam tipe ini adalah penulis mempublikasikan suatu artikel pada lebih dari satu redaksi publikasi. Dan mendaur ulang karya tulis/karya ilmiah.

Sesuai Peraturan Menteri Pendidikan Nasional

Republik Indonesia No. 17 Tahun 2010 tentang Pencegahan dan Penanggulangan Plagiat di Perguruan Tinggi, bentuk atau lingkup plagiarisme adalah:

1. Mengacu dan/atau mengutip istilah, kata-kata dan/atau kalimat, data dan/atau informasi dari suatu sumber tanpa menyebutkan sumber dalam catatan kutipan dan/atau tanpa menyatakan sumber secara memadai.

2. Mengacu dan/atau mengutip secara acak istilah, kata-kata dan/atau kalimat, data dan/atau informasi dari suatu sumber tanpa menyebutkan sumber dalam catatan kutipan dan/atau tanpa menyatakan sumber secara memadai.

3. Menggunakan sumber gagasan, pendapat, pandangan atau teori tanpa menyatakan sumber

\footnotetext{
${ }^{9}$ Parafrase adalah mengubah pendapat atau kalimat orang lain ke dalam susunan kalimat sendiri tanpa mengubah idenya.

${ }^{10}$ Soelistyo, H, Plagiarisme: Pelanggaran Hak Cipta dan Etika, Kanisius, Yogajakarta, 2001.
}

secara memadai.

4. Merumuskan dengan kata-kata dan/atau kalimat sendiri dari sumber kata-kata dan/atau kalimat, gagasan, pendapat, pandangan atau teori tanpa menyatakan sumber secara memadai.

5. Menyerahkansuatukaryailmiahyangdihasilkan dan/atau telah dipublikasikan oleh pihak lain sebagai karya ilmiahnya tanpa menyatakan sumber secara memadai.

\section{Plagiarisme Dalam Hukum Positif Indonesia}

Sesungguhnya, permasalahan tentang plagiarisme bukanlah hal yang baru di Indonesia dan bahkan di dunia. Secara internasional, beberapa negara di dunia telah bertekad untuk menanggulangi pembajakan atau pencurian di bidang karya cipta, termasuk karya ilmiah (karangan) melalui suatu konvensi internasional yang dikenal dengan Konvensi Bern tahun 1886 tentang International Convention for the Protection of Literary and Artistic Work yang secara berturut-turut diadakan revisi pada tahun 1908 di Berlin, tahun 1928 di Roma, tahun 1948 di Brussel, tahun 1967 di Stockholm dan tahun 1971 di Paris.

Karya-karya yang dilindungi melalui konvensi ini adalah meliputi, karya sastera, ilmiah, artistik dalam bentuk buku, selebaran, ceramah, pidato, kotbah, segala bentuk bahan tertulis, karya drama atau drama musikal, koreografi dan hiburan dalam pertunjukan, bentuk akting yang ditulis dalam bentuk skenario, komposisi musik, gambar, lukisan, karya arsitektur, karya ukiran/pahatan, karya ilustrasi, peta, sketsa, karya plastik yang berhubungan dengan geografi, arsitektur dan ilmu pengetahuan. Selain itu, juga termasuk karya-karya terjemahan, saduran, aransemen musik dan karyakarya reproduksi sastera dan artistik serta koleksikoleksi berbagai hasil karya.

Indonesia sendiri telah ikut serta dalamkonvensi ini dengan meratifikasikannya melalui Keputusan PresidenNo.18Tahun1997.KeikutsertaanIndonesia dalam konsvensi ini sekaligus menunjukkan tekat dan komitmen Indonesia dalam penegakan hukum pelanggaran hak cipta sekaligus menunjukkan kepada dunia bahwa bangsa Indonesia adalah bangsa pencipta (creator) dan bukan bangsa peniru.

Peraturan perundang-undangan hukum positif di Indonesia yang mengatur tentang plagiarisme adalah Kitab Undang Undang Hukum Pidana, tepatnya dalam Pasal 380 yang menentukan: 
(1) Diancam dengan pidana penjara paling lama dua tahun delapan bulan atau denda paling banyak lima ribu rupiah:

1. Barang siapa menaruh suatu nama atau tanda secara palsu di atas atau di dalam suatu hasil kesusasteraan, keilmuan, kesenian dan kerajinan atau memalsu nama atau tanda yang asli dengan maksud supaya karenanya orang mengira bahwa itu benar-benar buah hasil orang yang nama atau tandanya olehnya ditaruh di atas atau didalamnya tadi.

2. Barang siapa dengan sengaja menjual, menawarkan, menyerahkan, mempunyai persediaan ke Indonesia, buah hasil kesusasteraan, kesenian, keilmuan dan kerajinan yang di-dalamnya atau di atasnya telah ditaruh nama atau tanda yang palsu atau yang nama dan tandanya yang asli telah dipalsukan seakan-akan itu benar-benar buah hasil orang yang nama atau tandanya telah ditaruh secara palsu tadi.

(2) Jika buah hasil itu kepunyaan terpidana, boleh dirampas.

Dalam persfektif peraturan perundangundangan hak cipta yang tersebut dalam UU No. 28 Tahun 2014 tentang Hak Cipta, permasalahan plagiarisme tidak secara khusus mendapat pengaturan, namun demikian, undang-undang ini cukup mengatur pembatasan tentang tindakan plagiarisme sebagaimana diatur dalam Pasal 44 ayat (1) huruf (a) yang merumuskan secara negatif dengan menentukan "penggunaan, penganbilan, penggandaan dan/atau pengubahan suatu ciptaan dan/atau produk hak terkait secara seluruh atau sebagian yang substansial tidak dianggap sebagai pelanggaran hak cipta jika sumbernya disebutkan atau dicantumkan secara lengkap untuk keperluan pendidikan, penelitian, penulisan karya ilmiah, penyusunan laporan, penulisan kritik atau tinjauan suatu masalah dengan tidak merugikan kepentingan yang wajar dari pencipta atau pemegang hak cipta.

Berdasarkan ketentuan tersebut, diketahui bahwa syarat mencantumkan sumber adalah mutlak untuk dapat terbebas dari tindakan

pelanggaran hukum. Dengan pengertian, jika sumbernya tidak dicantumkan, maka perbuatan tersebut dikategorikan pelanggaran hak cipta, sekalipun dalam sanksi pidana melalui Pasal 113 UU No. 28 Tahun 2014 tidak secara eksplisit disebutkan ancaman hukuman bagi pelanggar hak cipta dalam Pasal 44 ini. Lebih lanjut harus digarisbawahi bahwa sekalipun dicantumkan sumbernya, masih tetap terbuka kemungkinan pengambilan itu diancam sebagai pelanggaran hak cipta, yaitu apabila pengambilan tersebut ternyata sampai merugikan kepentingan yang wajar dari pencipta. Pembentuk undang-undang menyadari bahwa pembatasan secara kuantitatif sulit untuk dilakukan sehingga pembatasan dalam ketentuan ini berdimensi kualitatif. Penjelasan Pasal 44 ayat (1) menjelaskan yang dimaksud dengan "sebagian yang substansial" adalah bagian yang paling penting dan khas yang menjadi ciri dari ciptaan. Sedangkan "kepentingan yang wajar dari pencipta dan pemegang hak cipta" adalah kepentingan yang didasarkan pada keseimbangan dalam menikmati manfaat ekonomis atas suatu ciptaan. ${ }^{11}$

Pembatasan secara kualitatif dengan menggunakan kata-kata "sebagian yang substansial" merupakan sesuatu yang sangat penting untuk diperhatikan. Dalam arti, tidak ada lagi alasan untuk melakukan pengambilan hak cipta orang lain dengan dalih "hanya satu atau dua kalimat atau paragrap". Karena sepanjang kalimat atau pragraf itu sifatnya substansial dan dilakukan tanpa mencantumkan sumbernya, maka hal tersebut sudah merupakan pelanggaran hak cipta yang dapat diancam dengan pidana.

Dalampersfektifperaturanperundang-undangan bidang pendidikan tinggi melalui UU No. 20 Tahun 2003 tentang Sistem Pendidikan Nasional, Yulianti mengemukakan bahwa UU Pendidikan Nasional tidak menyebutkan secara eksplisit tentang konsep tindakan plagiarisme, akan tetapi undang-undang ini memberikan kewenangan pada institusi pendidikan tinggi untuk memberikan gelar akademik pada peserta didik yang memenuhi peresyaratan yang telah ditetapkan, selain itu institusi pendidikan tinggi juga diberikan kewenangan untuk mencabut dan membatalkan gelar yang telah diberikan jika terbukti ada tindakan plagiarisme. Hal ini diatur dalam Pasal 25 UU No. 20 Tahun 2003. Tindakan plagiarisme tidak mendukung fungsi pendidikan nasional karena potensi, kemampuan dan watak serta peradaban bangsa yang bermartabat dalam

\footnotetext{
${ }^{11}$ Melalui Penjelasan Pasal 15 UU No. 19 Tahun 2002 tentang hak Cipta (sudah tidak belaku lagi dengan UU No. 28 Tahun 2014 tentang Hak Cipta) diketahui bahwa adanya aturan tidak tertulis yang diterapkan di berbagai negara adalah ukuran kuantitatif $10 \%$. Namun demikian, penentuan pengambilan unsur terpenting ini tewtap saja menimbulkan kesulitan karena penentuan "bagian terpenting" dari ciptaan karena bisa sangat subjektif.
} 
rangka mencerdaskan kehidupan bangsa dan tidak akan berbentuk, terutama bagi pelaku yang tidak memikirkan tindakan dan akibatnya bagi masyarakat. Ketentuan dalam Pasal 25 ini ditindak lanjuti oleh pemerintah dengan mengeluarkan Peraturan Menteri Pendidikan Nasional Republik Indonesia No. 17 Tahun 2010 tentang Pencegahan dan Penanggulangan Plagiat di Perguruan Tinggi. ${ }^{12}$

Pasal70UUNo. 20Tahun 2003 menentukanbahwa lulusan yang karya ilmiah yang digunakannya untuk mendapatkan gelar akademik, profesi, atau vokasi sebagaimana dimaksud dalam Pasal 25 ayat $(2)^{13}$ terbukti merupakan jiplakan dipidana dengan pidana penjara paling lama dua tahun dan/atau pidana denda paling banyak Rp 200.000.000,00 (dua ratus juta rupiah).

Selain dalam UU No. 20 Tahun 2003 tentang Sistem Pendidikan Nasional, secara institusional di Pendidikan Tinggi diatur dalam dalam UU No. 12 Tahun 2012 tentang Pendidikan Tinggi. Pasal 28 ayat (5) menentukan bahwa gelar akademik, gelar vokasi atau gelar profesi dinyatakan tidak sah sah dan dicabut oleh Perguruan Tinggi apabila karya ilmiah yang digunakan untuk memperoleh gelar akademik, gelar vokasi atau gelar progesi terbukri merupakan hasil jiplakan atau plagiat.

\section{Sanksi Pidana dalam Plagiarisme}

Pertanyaannya: bagaimana sanksi hukum yang dapat dijatuhkan kepada pelaku plagiarisme? Plagiarisme sering sekali hanya dianggap sebagai pelanggaran etika bukan pelanggaran hukum. Oleh sebab itu, untuk meluruskan anggapan sedemikian dibawah ini akan diuraikan sanksi hukum yang dapat dijatuhkan kepada seorang plagiator. Sesuai dengan hukum positif di Indonesia, berbagai bentuk ancaman atau sanksi hukum yang dapatdijatuhkan kepada seorang plagiator, mulai dari hukuman peringatan, pencabutan hak-hak tertentu, termasuk hukuman penjara atau denda dan ganti rugi secara perdata.

\footnotetext{
${ }^{12}$ Yuliati, Perlindungan Hukum Bagi Pencipta Berkaitan dengan Plagiarisme Karya Ilmiah di Indonesia dalam Jurnal Arena Hukum, Volume 6 Nomor 1, April 2012, halaman 59-60.

${ }^{13}$ Pasal 25 ayat (2) UU No. 20 tahun 2003 tentang Sistem Pendidikan Nasional menentukan bahwa lulusan perguruan tinggi yang karya ilmiahynya digunakan untuk memperoleh gelar akademik, profesi atau vokasi terbukti merupakan jiplakan dicabut gelarnya.
}

Sanksi pidana yang dapat dikenakan kepada seorang plagiator atas perbutannya sebagaimana diurakan di atas, secara umum diatur dalam Pasal 380 KUHP dengan ancaman hukuman maksimal 2 (dua) tahun delapan bulan, yang menurut R. Soesilo merupakan pasal yang mengancam hukuman terhadap perbuatan-perbuatan penipuan tentang hak cipta (auteursrecht atau copyright).${ }^{14}$ Selain itu terdapat dan diatur dalam Pasal 113 UU No. 28 Tahun 2014 tentang Hak Cipta dengan ancaman hukuman paling lama 4 (empat) tahun penjara dan atau denda paling banyak Rp. 1.000.000.000,- (satu milyar rupiah). Dalam persfektif UU No. 20Tahun 2003 tentang Sistem Pendidikan Nasional melalui Pasal 70 ancaman hukumannya adalah penjara maksimal 2 (dua) tahun dan/atau denda paling banyak Rp. 200.000.000,- (dua ratus juta rupiah). Juga adalah sanksi pencabutan gelar melalui Pasal 25 ayat (2).

Permasalahan dalam tataran praktik adalah terdapatnya perbedaan jenis kejahatan dan beratnya hukuman yang dapat dijatuhkan atas tindakan plagiarisme tersebut yang diatur dalam Pasal 380 KUHP dan UU No. 20 Tahun 2003 tentang Sistem Pendidikan Nasional di satu sisi dan Pasal 113 UU No. 28 Tahun 2014 tentang Hak Cipta di sisi lain. Menurut Pasal 380 KUHP dan Pasal 70 UU No. 20 Tahun 2003, jenis kejahatan atas perbuatan plagiarism adalah kejahatan biasa sedangkan jenis kejahatan menurut UU No. 28 Tahun 2014 adalah merupakan delik aduan. Pengaturan yang sangat berbeda termasuk ancaman hukumannya sebagaimana di-uraikan di atas.

Selain sanksi pidana atas perbuatan plagiarism sebagaimana diuraikan di atas, terdapat juga sanksi perdata, yaitu seorang plagiator dapat digugat secara perdata atas perbuatan yang dilakukannya berdasarkan gugatan perbuatan melawan hukum sesuai Pasal 1365 KUHPerdata yang menentukan tiap perbuatan yang melanggar hukum dan membawa kerugian kepada orang lain, mewajibkan orang yang menimbulkan kerugian itu karena kesalahannya untuk menggantikan kerugian tersebut. Hal yang sama diatur dalam Pasal 28 ayat (5) UU No. 12 Tahun 2012 tentang Pendidikan Tinggi terkait sanksi pencabutan gelar akademik, gelar vokasi atau gelar profesi.

\footnotetext{
${ }^{14}$ R. Soesilo, Kitab Undang Undang Hukum Pidana (KUHP) Serta Komentar-Komentarnya Lengkap Pasal Demi Pasal, Politeia, Bogor, 1981, halaman 227.
} 
Selanjutnya melalui Pasal 92 UU No. 12 Tahun 2012 tentang Pendidikan Tinggi ditetapkan sanksi atau ancaman hukuman bagi institusi Perguruan Tingginya berupa sanksi administratif dalam bentuk:

1. Peringatan tertulis

2. Penghentian sementara bantuan biaya pendidikan dari pemerintah

3. Penghentian smentara kegiatan penyelenggaraan pendidikan

4. Penghentian pembinaan; dan/atau

5. Pencabutan izin

Secara khusus di lingkungan pendidikan tinggi, sanksi bagi seorang plagiator ditetapkan melalui Pasal 12 ayat (1) sampai dengan (3) yaitu:

(1) Sanksi bagi mahasiswa yang terbukti melakukan plagiat sebagaimana dimaksudkan dalam Pasal 10 ayat (4) ${ }^{15}$, secara berurutan dari yang paling ringan sampai dengan yang paling berat, terdiri dari:

a. Teguran

b. Peringatan tertulis

c. Penundaan pemberian sebagian hak mahasiswa

d. Pembatalan nilai satu atau beberapa mata kuliah yang diperoleh mahasiswa

e. Pemberhentian dengan hormat dari status sebagai mahasiswa

f. Pemberhentian tidak dengan hormat dari status sebagai mahasiswa, atau

g. Pembatalan ijazah apabila mahasiswa telah lulus dari suatu program

(2) Sanksi bagi dosen/peneliti/tenaga kependidikan yang terbukti melakukan plagiat sebagaimana dimaksudkan dalam Pasal 11 ayat $(6)^{16}$, secara berurutan dari yang paling ringan sampai dengan yang paling berat, terdiri dari:
a. Teguran
b. Peringatan tertulis
c. Penundaan pemberian hakdosen/peneliti/

\footnotetext{
${ }^{15}$ Pasal 10 ayat (4) menentukan apabila berdasarkan persandingan dan kesaksian telah terbukti terjadi plagiat, maka ketua jurusan/ departemen/bagian menjatuhkan sanksi kepada mahasiswa sebagai plagiator.

${ }^{16}$ Pasal 11 ayat (6) menentukan apabila berdasarkan persandingan dan hasil telaah telah terbukti terjadi plagiat, maka senat akademik/ organ lain yang sejenis merekomendasikan sanksi untuk dosen/ peneliti/tenaga kependidikan sebagai plagiator kepada Pemimpin/ Pimpinan Perguruan Tinggi untuk dilaksanakan.
}

tenaga kependidikan

d. Penurunan pangkat dan jabatan akademik/ fungsional

e. Pencabutan hak untuk diusulkan sebagai guru besar/professor/ahli peneliti utama bagi yang memenuhi syarat

f. Pemberhentian dengan hormat dari status sebagai dosen/peneliti/tenaga kependidikan

g. Pemberhentian dengan tidak hormat dari status sebagai dosen/peneliti/tenaga kependidikan; atau

h. Pembatalan ijazah yang diperoleh dari perguruan tinggi yang bersangkutan

(3) Apabila dosen/peneliti/tenaga kependidikan sebagaimana dimaksud pada ayat (2) huruf f, huruf $\mathrm{g}$ dan huruf $\mathrm{h}$ menyandang sebutan guru besar/professor/ahli peneliti utama, maka dosen/peneliti/tenaga kependidikan tersebut dijatuhi sanksi tambahan berupa pemberhentian dari jabatan guru besar/ professor/ahli peneliti utama oleh Menteri atau pejabat yang berwenang atas usul perguruan tinggi yang diselenggarakan oleh Pemerintah atau atas usul perguruan tinggi yang diselenggarakan oleh masyarakat melalui Koordinator Perguruan Tinggi Swasta.

Bagaimana cara untuk bisa terhindar dari tindakan plagiarisme? Prinsip dasar untuk menghindari dari perbuatan plagiarisme adalah sikap jujur dan menghargai serta mengormati karya atau ide atau pendapat orang lain. Dalam kaitannya dengan penyusunan suatu karya ilmiah dalam berbagai bentuknya, maka tindakan plagiarisme dapat dihindari dengan melakukan pengutipan dan/atau melakukan parafhrase dengan menyebutkan sumbernya, yaitu sebagai berikut:

1. Pengutipan

a. Menggunakan dua tanda kutif jika mengambil langsung satu kalimat dengan menyebutkan sumbernya.

b. Menuliskan daftar pustaka atas karya yang ditunjuk dengan baik dan benar.

2. Parafrase

Melakukan paraphrase dengan tetap menyebutkan sumbernya. Catatan, terkait dengan cara atau bentuk pengutipan apakah dalam bentuk catatan kaki (footnote) atau 
catatan pinggir (endnote) dan catatan perut diatur sendiri oleh perguruan tinggi/program studi yang bersangkutan dalam Pedoman Penulisan Karya Tulis atau Skripsi atau Tugas Akhir.

\section{Kesimpulan dan Saran}

Plagiarisme adalah perbuatan pengambilan karangan, ide, pendapat atau karya orang lain tanpa menyebutkan sumbernya secara lengkap dan menjadikannya seolah-olah menjadi karya, ide atau pendapat sendiri. Hasil dari plagiarisme disebut plagiat sedangkan pelakunya disebut plagiator. Plagiarisme tidak saja merupakan pelanggaran etika dan moral, melainkan merupakan pelanggaran hukum dengan ancaman hukum mulai dari pencabutan hak-hak tertentu seperti pencabutan gelar dan sejenisnya hingga ancaman hukum penjara termasuk denda dang anti rugi secara perdata. Plagiarisme telah merupakan kejahatan intelektual.

Pengaturan plagiarisme dalam hukum positif di Indonesia terdapat sejumlah peraturan perundangundangan, yaitu dalam Kitab Undang Undang Hukum Pidana (KUHP), peraturan perundanganundangan hak cipta dalam UU No. 28 Tahun 2014 tentang Hak Cipta, dan UU No. 20 Tahun 2003 tentang Sistem Pendidikan Nasional dan untuk yang lebih operasional dalam Peraturan Menteri Pendidikan Nasional Republik Indonesia No. 17 Tahun 2010 tentang Pencegahan dan Penanggulangan Plagiat di Perguruan Tinggi serta UU No. 12 Tahun 2012 tentang Pendidikan Tinggi Perguruan Tinggi dituntut sebagai sebagai institusi yang bertanggung jawab untuk mengawasi dan menanggulangi terjadinya plagiarisme di lingkungan Perguruan Tinggi. Untuk menghindari tindakan plagiarisme setiap orang dituntut untuk berlaku jujur dan mempunyai integritas yang tinggi, menghargai dan menghormati karya, ide, pendapat orang lain. 


\section{Daftar Pustaka}

Brotowidjojo, M.D, Penulisan Karangan Ilmiah, Edisi Kedua, Akademika Pressiondo, Jakarta, 1993.

Departemen Pendidikan Nasional, Kamus Besar Bahasa Indonesia, Edisi Ketiga, Balai Pustaka, Jakarta, 2005.

Echols dan Shadiliy, Kamus Inggris Indonesia, Gramedia, Jakarta, 1983.

Panjaitan Hulman dan Wetmen Sinaga, Performing Right Hak Cipta Atas Karya Cipta Musik dan Lagu serta Aspek Hukumnya, Ido Hill Co, Jakarta, 2010.

Soelistyo, H, Plagiarisme: Pelanggaran Hak Cipta dan Etika, Kanisius, Yogajakarta, 2001.

Soesilo R, Kitab Undang Undang hukum Pidana (KUHP) Serta Komentar-Komentarnya Lengkap Pasal Demi Pasal, Politeia, Bogor, 1981.

Jurnal Arena Hukum, Volume 6 Nomor 1, April 2012,

\section{Peraturan Perundang Undangan}

Kitab Undang Undang Hukum Pidana Kitab Undang Undang Hukum Perdata

UU No. 20 Tahun 2003 tentang Sistem Pendidikan Nasional

UU No. 12 Tahun 2012 tentang Pendidikan Tinggi UU No. 28 Tahun 2014 tentang Hak Cipta

Peraturan Menteri Pendidikan Nasional Republik

Indonesia No. 17 Tahun 2010 tentang

Pencegahan dan Penanggulangan Plagiat di Perguruan Tinggi. 